\title{
Human Red Cell Aquaporin CHIP \\ I. Molecular Characterization of ABH and Colton Blood Group Antigens
}

Barbara L. Smith, ${ }^{\star}$ Gregory M. Preston, ${ }^{\star}$ Frances A. Spring, ${ }^{\ddagger}$ David J. Anstee, ${ }^{\ddagger}$ and Peter Agre*

*Departments of Medicine and Biological Chemistry, Johns Hopkins University School of Medicine, Baltimore, Maryland 21205-2185; and ${ }^{\ddagger}$ International Blood Group Reference Laboratory, Bristol, BS10 5ND United Kingdom

\begin{abstract}
Blood group antigens are structural variants in surface carbohydrate or amino acid polymorphisms on extracellular domains of membrane proteins. The red cell water channelforming integral protein (Aquaporin CHIP) is a homotetramer with only one $N$-glycosylated subunit, however no CHIP-associated blood group antigens have yet been identified. Immunoblotting, monosaccharide composition analysis, and selective glycosidase digestions revealed that the CHIP-associated oligosaccharide contains ABH determinants and resembles a band 3-type glycan that cannot be cleaved from intact membranes by Peptide: $N$-glycosidase $F$. The molecular structure of the Colton antigens was previously unknown, but CHIP was selectively immunoprecipitated with anti-Co or anti-Co ${ }^{b}$. The DNA sequence from Colton-typed individuals predicted that residue $\mathbf{4 5}$ is alanine in the $\mathrm{Co}(\mathrm{a}+\mathrm{b}-)$ phenotype and valine in the $\mathrm{Co}(\mathrm{a}-\mathrm{b}+)$ phenotype. The nucleotide polymorphism corresponds to a PfIMI endonuclease digestion site in the DNA from $\mathrm{Co}(\mathbf{a}-\mathbf{b}+)$ individuals. These studies have defined antigens within two blood group systems on CHIP: (a) an ABHbearing polylactosaminoglycan attached to a poorly accessible site in the native membrane; and $(b)$ the Colton antigen polymorphism which may permit the identification of rare individuals with defective water channel expression. (J. Clin. Invest. 1994. 94:1043-1049.) Key words: erythrocyte membrane $\bullet$ blood group antigens $\bullet$ water channels $\bullet$ membrane protein glycosylation
\end{abstract}

\section{Introduction}

The field of human genetics originated from the study of human blood group antigens. Approximately 250 antigens have been described serologically and are members of 22 different blood group systems (1). The $\mathrm{ABH}$ antigens and a few other blood group antigens are known to be specific oligosaccharide structures formed by glycosyltransferases with altered monosaccharide specificities caused by polymorphisms in their genes (2).

This study was presented at the annual meeting of the American Federation for Clinical Research in Baltimore, MD on 1 May 1994 and was published in abstract form (1994. Clin. Res. 42:238a).

Address correspondence to Peter Agre, Johns Hopkins University School of Medicine, 725 North Wolfe Street, Baltimore, MD 21205.

Received for publication 7 April 1994 and in revised form 24 May 1994.

J. Clin. Invest.

(c) The American Society for Clinical Investigation, Inc. 0021-9738/94/09/1043/07 \$2.00

Volume 94, September 1994, 1043-1049
As seen within the MNSs system, the structures of many blood group antigens may result from amino acid substitutions in surface domains of red cell membrane proteins (for reviews see references 3 and 4 ), whereas other antigens such as $\mathrm{Wr}^{\mathbf{b}}$ may result from the juxtaposition of two known membrane structures (5). Search for the molecular structures of blood groups Rh (6, 7), Kell (8), and Duffy (9) led to the identification of new red cell membrane proteins. Nevertheless, the molecular identities of several blood group antigens remain unknown.

Channel-forming integral protein (CHIP) ${ }^{1}$ is an abundant membrane protein of red cells and renal proximal tubules (1013). CHIP functions as a water-selective pore $(14,15)$ and is the archetypal member of the Aquaporin family of water transporters found in animals and plants $(16,17)$. The structure of CHIP has been partially characterized; the amino acid sequence deduced from the cDNA encodes a protein with six presumed bilayer-spanning domains, internal amino and carboxy termini, and two potential $\mathrm{N}$-glycosylation sites (18). CHIP exists as a homotetramer comprised of identical, noncovalently associated subunits, although only one of four subunits contains an $\mathrm{N}$-linked glycan (11). Asparagine- 42 was shown to be the glycosylation site, and the proposed membrane topology of biologically active CHIP molecules was confirmed by insertional mutagenesis (19). The tetrameric organization is supported by freeze fracture of CHIP proteoliposomes $(20,21)$ and by high resolution electron microscopic analysis of twodimensional membrane crystals which retained full biological activity (22).

CHIP was first identified because it contaminated preparations of the Rh membrane proteins $(23,24)$, however no CHIPassociated red cell antigens are known. Although its electrophoretic mobility is similar to the band 3 polylactosaminoglycan (25), the structure of CHIP-glycan is undefined, and the substoichiometric glycosylation remains unexplained. The locus of Aquaporin-1, the gene encoding CHIP, was identified at human chromosome $7 \mathrm{p} 14$ (26). This location is coincident with the location of the Colton blood group locus on $7 p$ (27). The present study was conducted to characterize the CHIP-glycan and to determine if CHIP is the molecular site of the Colton polymorphism.

\section{Methods}

Materials. Polyclonal, affinity-purified rabbit antibodies to CHIP were previously described $(11,13)$. Anti-glyRh was obtained from rabbits immunized with partially purified Rh protein $(23,24)$; anti-CHIP immunoglobulin was removed by CHIP affinity chromatography $(10,11)$. Typed red cells and antisera were obtained through the American Red

1. Abbreviations used in this paper: CHIP, channel-forming integral protein; CHIP28, nonglycosylated 28-kD subunit; glyCHIP, glycosylated $40-60-\mathrm{kD}$ subunit. 
Cross, Maryland Affiliate, the Johns Hopkins Hospital Blood Bank, or the International Blood Group Reference Laboratory. Red cells from two donors of type $\mathrm{Co}(\mathrm{a}-\mathrm{b}+)$ were obtained from the National Blood Transfusion Service (Cardiff, Wales). Human anti-Co3 was a gift from J. Moulds (Gamma Biologicals, Houston, TX). Molecular biologic enzymes and reagents were from GIBCO BRL (Gaithersburg, MD). Glycosidases were from Genzyme Corp. (Cambridge, MA). Carrier free ${ }^{125} I$ was from New England Nuclear (Boston, MA). Other reagents and supplies were from Bio-Rad (Melville, NY), Schwarz/Mann (Spring Valley, NY), Sigma Immunochemicals (St. Louis, MO), Pharmacia LKB Biotechnology, Inc. (Piscataway, NJ), Eastman Kodak Co. (Rochester, NY), or J. T. Baker, Inc. (Phillipsburg, NJ).

Electrophoresis and immunoblot methods. SDS-PAGE was performed with the buffer system of Laemmli (28), and immunoblotting was performed with visualization by ${ }^{125}$ I-protein A autoradiography (11) or enhanced chemiluminescence (Amersham Corp., Arlington Heights, IL) as described (13).

Carbohydrate studies, $A$ and $B$ antigens. CHIP protein was purified from group $\mathrm{A}, \mathrm{B}, \mathrm{AB}$, and $\mathrm{O}$ red cells by hydroxylapatite chromatography in SDS (11). Nonglycosylated CHIP (28 kD) and glyCHIP (40-60 $\mathrm{kD}$ ) were separated by preparative SDS-PAGE and eluted into $0.1 \%$ SDS, $10 \mathrm{mM}$ sodium phosphate (pH 7.2), $1 \mathrm{mM} \mathrm{Na} \mathrm{N}_{2}$ EDTA and concentrated over a Centricon-10 (Amicon, Beverly, MA). The samples were analyzed by SDS-PAGE immunoblot by reaction with human primary antisera (anti-A or anti-B [Immucor, Norcross, GA] or anti-A,B [Ortho Pharmaceutical, Raritan, NJ]) and rabbit anti-human IgM secondary antiserum, with visualization by ${ }^{125} \mathrm{I}$-protein $\mathrm{A}$ autoradiography.

Glycosidase studies. CHIP protein was purified in Triton X-100 by Mono $\mathrm{Q}$ chromatography, and $\sim 20 \mu \mathrm{g}$ of protein was precipitated with $-20^{\circ} \mathrm{C}$ acetone, resuspended in $6 \% \mathrm{SDS}, 50 \mathrm{mM}$ sodium phosphate $(\mathrm{pH}$ 7.4), and labeled with carrier free ${ }^{125} \mathrm{I}$ by chloramine $\mathrm{T}$ oxidation as described (11). The ${ }^{125}$ I-CHIP and ${ }^{125}$ I-glyCHIP subunits were separated by SDS-PAGE. The gel slices were washed extensively in $10 \%$ methanol, freeze dried, and digested with $100 \mu \mathrm{g} / \mathrm{ml}$ of $\alpha$-chymotrypsin in 50 $\mathrm{mM} \mathrm{NH} \mathrm{HCO}_{3}$ at $37^{\circ} \mathrm{C}$ for $12 \mathrm{~h}$ and again with fresh protease for $6 \mathrm{~h}$. Fractions corresponding to the ${ }^{125}$ I-glycopeptides were injected onto a Superose 12 column equilibrated with $20 \mathrm{mM}$ Tris- $\mathrm{HCl}(\mathrm{pH} 7.5), 0.2$ $\mathrm{mM} \mathrm{NaCl}$ running at $1 \mathrm{ml} / \mathrm{min}$. ${ }^{125}$ I-glycopeptide fractions were suspended in deionized water, and aliquots were digested for $20 \mathrm{~h}$ at $37^{\circ} \mathrm{C}$ with the following glycosidases as specified (Genzyme Corp.): (a) endoglycosidase $\mathrm{H}, 10 \mathrm{mU}$ in $50 \mu \mathrm{l} 50 \mathrm{mM}$ sodium phosphate (pH 6), 1 $\mathrm{mM}$ phenylmethylsulfonyl fluoride (activity confirmed by digestion of ovalbumin); (b) endo- $\beta$-galactosidase, $50 \mathrm{mU}$ in $50 \mu \mathrm{l}$ sodium acetate (pH 5.8), $0.2 \mathrm{mg} / \mathrm{ml}$ bovine serum albumin; (c) Peptide: $N$-glycosidase $\mathrm{F}$ ( $N$-glycanase), $0.5 \mathrm{U}$ in $50 \mu 10.1 \% \mathrm{SDS}, 1 \%$ Nonidet $\mathrm{P}-40,150 \mathrm{mM}$ sodium phosphate (pH 7.4), $30 \mathrm{mM} \beta$-mercaptoethanol, $10 \mathrm{mM} \mathrm{1,10}$ phenanthroline. Control tubes were incubated identically without glycosidase. The digests were analyzed by Superose 12 chromatography.

Monosaccharide compositional analysis. CHIP protein was purified from $100 \mathrm{ml}$ of human group $\mathrm{AB}$ red cells by POROS $\mathrm{Q} / \mathrm{H}$ chromatography (15). SDS was added to a final concentration of $1 \%$, and $900 \mu \mathrm{g}$ CHIP protein was electrophoresed through a 5-cm SDS-PAGE acrylamide column using a model 491 Prep Cell (Bio-Rad). The glyCHIP was eluted into electrophoresis buffer (28), concentrated over a Centricon-10 (Amicon), and washed with $0.01 \%$ SDS. Duplicate microtubes with $0.28 \mathrm{nmol}$ of glyCHIP protein or tubes with an equivalent volume of buffer control were precipitated with ethanol at $-20^{\circ} \mathrm{C}$. As a control, bovine fetuin $(0.82 \mathrm{nmol})$ was analyzed in parallel without alcohol precipitation. The samples were hydrolyzed by addition of $2 \mathrm{~N}$ trifluoroacetic acid or $6 \mathrm{~N} \mathrm{HCl}$, incubated for $4 \mathrm{~h}$ at $100^{\circ} \mathrm{C}$, and dried under vacuum. The hydrolysates were resuspended in $200 \mu \mathrm{l}$ deionized water. Samples equivalent to $0.122 \mathrm{nmol}$ of fetuin (known) or not more than $0.20 \mathrm{nmol}$ of glyCHIP (based on original starting material) were injected onto the Dionex Glyco Station (Dionex Corp., Sunnyvale, CA) and analyzed using manufacturer's instructions.

Colton immunoprecipitations, intact red cells. $1 \mathrm{ml}$ of packed red cells was incubated in $4 \mathrm{ml}$ of $5 \mathrm{mM}$ sodium phosphate ( $\mathrm{pH} 8), 150$ $\mathrm{mM} \mathrm{NaCl}$ (PBS) with $10 \mathrm{mg}$ of trypsin (bovine pancreas, 10,200 U/ $\mathrm{mg}$ ) for $45 \mathrm{~min}$ at $37^{\circ} \mathrm{C}$ and then was washed four times with PBS ( $\mathrm{pH}$ 7.3) as described (29). $5 \mathrm{ml}$ of anti-Co $\mathrm{Co}^{\mathrm{a}}$, anti-Co ${ }^{\mathrm{b}}$, or anti-Co3 serum was added and incubated for $1 \mathrm{~h}$ at $37^{\circ} \mathrm{C}$ and then incubated overnight at $4^{\circ} \mathrm{C}$. The red cells were pelleted and washed three times in $30 \mathrm{ml}$ of PBS, and membranes were prepared by lysis in $30 \mathrm{vol}$ of $5 \mathrm{mM}$ sodium phosphate ( $\mathrm{pH}$ 7.4) as described (30). The membranes were suspended in $6 \mathrm{vol} 2 \%(\mathrm{wt} / \mathrm{vol})$ Triton X-100 in PBS (pH 7.3) containing $2 \mathrm{mM}$ phenylmethylsulfonyl fluoride and $5 \mathrm{mM} \mathrm{K} \mathrm{K}_{2}$ EDTA (TX-PBS) for 15 min at $20^{\circ} \mathrm{C}$ before centrifugation $\left(40,000 \mathrm{~g}\right.$ for $30 \mathrm{~min}$ at $\left.4^{\circ} \mathrm{C}\right) .60 \mu \mathrm{l}$ of a $50 \%(\mathrm{vol} / \mathrm{vol})$ suspension of protein G Sepharose in TX-PBS was added to the supernatant for $1 \mathrm{~h}$. The resin was washed five times in the same buffer, and the immune complexes were eluted with 5\% SDS and analyzed by SDS-PAGE immunoblot.

Colton immunoprecipitations, Triton X-100-solubilized membranes. Group $O$ red cell membranes at $2 \mathrm{mg} / \mathrm{ml}$ were solubilized in 3\% (vol/ vol) Triton X-100, $20 \mathrm{mM}$ Tris- $\mathrm{HCl}$ (pH 7.5), $1 \mathrm{mM} \mathrm{Na}{ }_{2}$ EDTA, $1 \mathrm{mM}$ $\mathrm{NaN}_{3}$ by shaking for $1 \mathrm{~h}$ at $20^{\circ} \mathrm{C}$. After pelleting at $44,000 \mathrm{~g}$ for 45 $\mathrm{min}$ at $4^{\circ} \mathrm{C}$, the supernatant was diluted to $1 \%$ (vol/vol) Triton X-100 and divided into three aliquots and mixed with an equal volume containing: (a) group O pooled plasma (negative control); $(b)$ anti-Co ${ }^{\mathrm{a}}$ plasma from a group $\mathrm{O}$ donor (titer 64); or (c) $0.16 \mu \mathrm{g}$ of affinitypurified anti-CHIP (positive control). The tubes were incubated for 30 min at $37^{\circ} \mathrm{C}$ and then for $18 \mathrm{~h}$ at $4^{\circ} \mathrm{C}$ before addition of $0.5 \mathrm{vol}$ of protein A Sepharose CL-4B for $2 \mathrm{~h}$ at $4^{\circ} \mathrm{C}$. The resin was pelleted, washed three times with $0.1 \%$ Triton $\mathrm{X}-100$ in the same buffer, eluted in $2 \%(\mathrm{wt} / \mathrm{vol}) \mathrm{SDS}$, and analyzed by SDS-PAGE immunoblot with anti-CHIP.

Molecular genetic studies. Genomic DNA was isolated from peripheral blood lymphocytes and from EBV transformed lymphoblastoid cell lines as described (31). The following oligonucleotide primers corresponding to the four exons were used to amplify DNA templates (sequences complementary to those of the CHIP gene are in capital letters):

\subsection{S, 5'-gcgaaTTCAAGAAGAAGCTCTTCTGG-3'}

\subsection{A: 5'-cgggtACCAGTGCCTTTCAGCATCA-3'}

\subsection{S: 5'-cgggtACCAGTCCTCACCACCTCTC-3'}

\subsection{A: 5'-cggaaTTCCCCCACCTCCATCTGG-3'}

\subsection{S: 5'-CTATGACTCTCTGCCTTCGC-3'}

\subsection{A: 5'-GGGACACCAAAGCTTCCCAC-3'}

\subsection{S: 5'-GAGTGGAGCCCTCTGAACAC-3'}

\subsection{A: 5'-CAGACCCCTTCTATTTGGGC-3'.}

Restriction endonuclease sites (underlined) facilitated directional subcloning of the PCR products. Sense oligonucleotide 1.1S is complementary to bases 13-33 of the human CHIP cDNA (18). Antisense oligonucleotide $4.1 \mathrm{~A}$ is complementary to sequences near exon IV translational termination sequences. Other oligonucleotides are complementary to sequences from splice donor (S) and acceptor (A) CHIP intron sequences (GenBank accession numbers L11321-L11326; reference 26).

Polymerase chain reactions contained 100 ng genomic DNA, 25 pmol of each primer, $0.2 \mathrm{mM}$ of each dNTP, $10 \mathrm{mM}$ Tris- $\mathrm{HCl}(\mathrm{pH}$ 8.3), $50 \mathrm{mM} \mathrm{KCl}$, and $0.7-1.0 \mathrm{mM} \mathrm{MgCl}{ }_{2}$ in a $50-\mu l$ volume. After denaturation for $5 \mathrm{~min}$ at $95^{\circ} \mathrm{C}$, AmpliTaq DNA polymerase (2 U; Perkin-Elmer Corp., Norwalk, CT) was added, and 35 cycles of amplification were performed: denaturation for $1 \mathrm{~min}$ at $94^{\circ} \mathrm{C}$, annealing for 1 min at $50-60^{\circ} \mathrm{C}$, and extension for $1 \mathrm{~min}$ at $72^{\circ} \mathrm{C}$. PCR products were separated on $3-4 \%$ agarose gels and stained with ethidium bromide. Exon I PCR samples of genomic DNA from two unrelated individuals with each of the phenotypes $\operatorname{Co}(a+b-), \operatorname{Co}(a+b+)$, and $\operatorname{Co}(a-b+)$ were also digested with PflMI (United States Biochemical Corp., Cleveland, $\mathrm{OH})$, run on a $6 \%$ polyacrylamide gel in TBE $(90 \mathrm{mM}$ Tris, $\mathrm{pH}$ $8.0,90 \mathrm{mM}$ boric acid, $2 \mathrm{mM} \mathrm{Na}{ }_{2}$ EDTA), and stained with ethidium bromide. The PCR products were gel purified and subjected to double- 

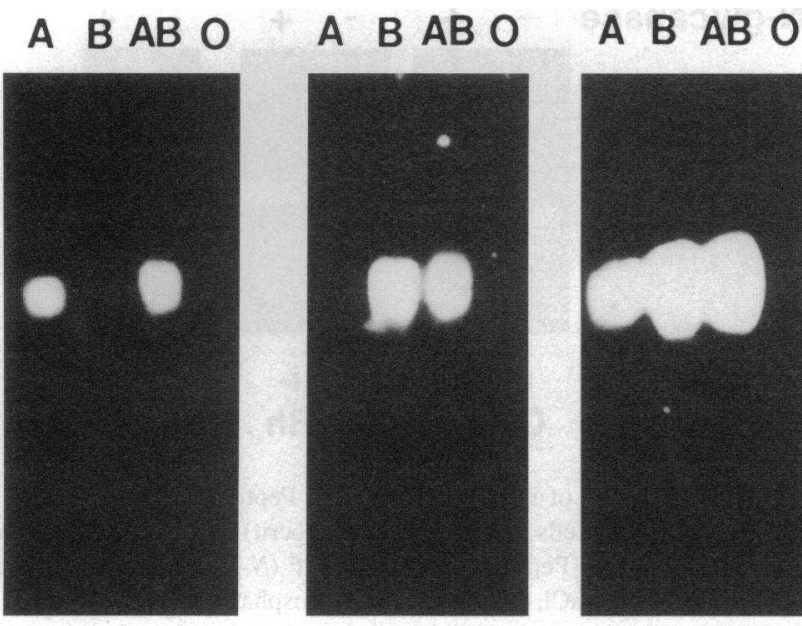

ANTI - A

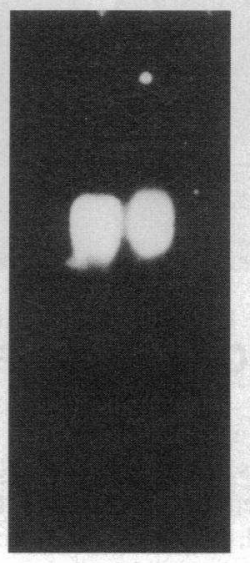

ANTI-B

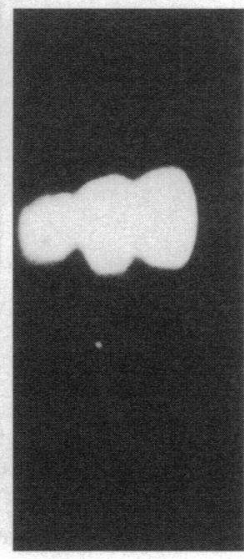

ANTI-A,B

Figure 1. Immunoblot analysis of Aquaporin glyCHIP subunits isolated from red cells of defined ABO phenotypes. Red cell CHIP protein from group $\mathrm{A}$, group $\mathrm{B}$, group $\mathrm{AB}$, and group $\mathrm{O}$ donors was purified to homogeneity, and 40-60-kD glyCHIP was isolated. Approximately 7 $\mu \mathrm{g}$ of glyCHIP protein was electrophoresed into $12 \%$ SDS-PAGE gels, transferred to nitrocellulose membrane, incubated with antisera specific for A and B antigenic structures, and visualized by autoradiography (see Methods).

stranded DNA sequencing (GIBCO BRL) with $\left[\gamma^{32} \mathrm{P}\right] \mathrm{ATP}(5,000 \mathrm{Ci} /$ mmol; Amersham Corp.). Exon I PCR products from $\mathrm{Co}(\mathrm{a}+\mathrm{b}-)$ and $\mathrm{Co}(\mathrm{a}-\mathrm{b}+)$ samples were also digested with EcoRI and KpnI, ligated into pBluescript II (Stratagene, La Jolla, CA), and sequenced by the dideoxynucleotide chain termination with Sequenase 2.0 (United States Biochemical Corp.).

\section{Results}

Aquaporin CHIP-glycan. Although a subset of CHIP subunits are known to bear asparagine-linked carbohydrates (11), the molecular composition of these oligosaccharides has not been defined. CHIP was purified to homogeneity from red cells of known ABO phenotype. To separate the $40-60-\mathrm{kD}$ glycosylated subunits (glyCHIP) from the $28-\mathrm{kD}$ nonglycosylated subunits, purified total CHIP was denatured by SDS, loaded onto a preparative SDS-PAGE slab gel, and the glyCHIP fractions were eluted and concentrated. Specific reactions were observed when the glyCHIP fractions from typed blood were analyzed by SDS-PAGE immunoblot with antisera specific for A and B blood group antigens (Fig. 1).

The structures of the CHIP-glycans were characterized further by digestion with specific glycosidases. Purified CHIP was labeled with ${ }^{125} \mathrm{I}$, and $28-\mathrm{kD}$ nonglycosylated CHIP subunits and 40-60-kD glycosylated subunits were eluted separately from preparative SDS-PAGE gels and digested with $\alpha$-chymotrypsin. Whole digests were then analyzed by gel filtration chromatography over a Superose 12 column (Fig. 2, $A$ and $B$ ). The profiles were identical except for a small peak with more rapid elution in the glyCHIP preparation (Fig. 2 B, bracket). This peak which consistently exhibited the same mobility when rechromatographed over the same column (not shown) represented the ${ }^{125} \mathrm{I}$ glycopolypeptides. Aliquots of the glyCHIP peak were digested with specific glycosidases, and the elution pattern of control

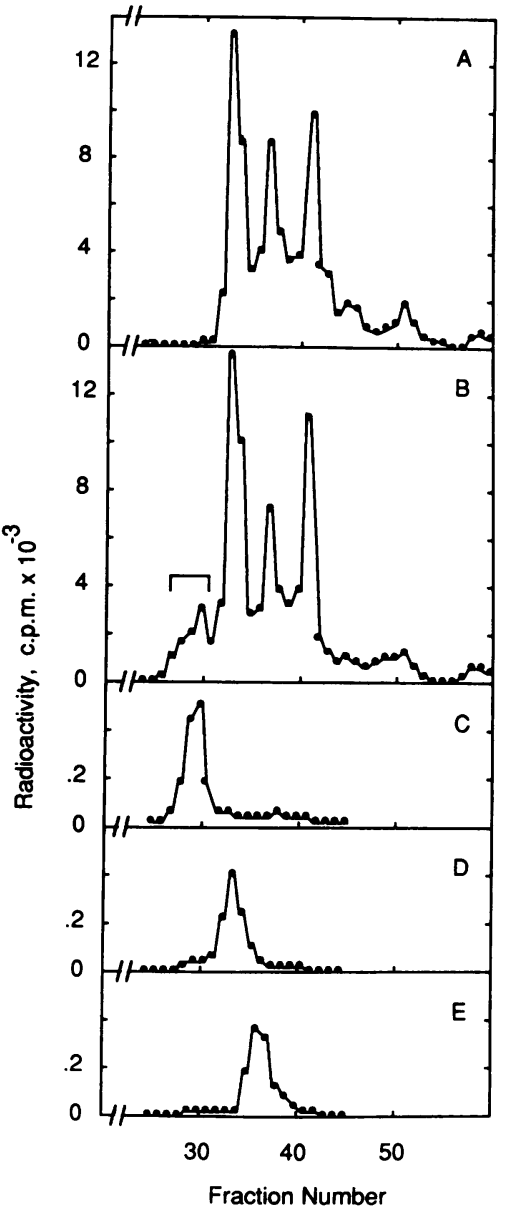

Figure 2. Gel filtration chromatography of ${ }^{125} \mathrm{I}$-glyCHIP peptide fragments after digestion with various glycosidases. $(A)$ Isolated $28-\mathrm{kD}$ CHIP or (B) $40-60-\mathrm{kD}$ glyCHIP was labeled previously with ${ }^{125} \mathrm{I}$, digested with $\alpha$-chymotrypsin, and injected onto a Superose 12 column while 0.5 -ml fractions were collected (see Methods). The ${ }^{125} \mathrm{I}$-glyCHIP peptide fraction $(B, b r a c k e t)$ was rechromatographed directly (not shown) or $(C)$ after digestion with endoglycosidase $H,(D)$ endo- $\beta$ galactosidase, or $(E)$ Peptide: $N$-glycosidase $\mathrm{F}$.

aliquots incubated without glycosidase was not altered (not shown). After digestion with endoglycosidase $\mathrm{H}$, the elution profile of ${ }^{125} \mathrm{I}$-glyCHIP was identical to the undigested control (Fig. $2 \mathrm{C}$ ), indicating the lack of high mannose structures within the glycan. The elution of ${ }^{125}$ I-glyCHIP was significantly retarded after digestion with endo- $\beta$-galactosidase (Fig. $2 \mathrm{D}$ ), indicating the existence of internal galactose- $N$-acetylglucosamine repeating units. A single peak with still slower chromatographic elution was found after digestion with Peptide: $N$-glycosidase $\mathrm{F}$, an enzyme known to strip the oligosaccharides from their asparagine linkage yielding free ${ }^{125} \mathrm{I}$-peptides (Fig. $2 \mathrm{E}$ ). Compositional analysis of oligosaccharides isolated from purified glyCHIP was performed with the Dionex Glyco Station (Dionex Corp.) which confirmed the existence of sugars known to comprise polylactosaminoglycans similar to that of band 3:Nacetylglucosamine, mannose, galactose, and fucose (Table I). In addition, the presence of $\mathrm{ABH}$ antigens within the CHIP glycan was also confirmed by the identification of the sugars which define $\mathrm{ABH}$ antigenic sites: $N$-acetylgalactosamine, galactose, and fucose. 
Table I. Monosaccharide Composition of CHIP-Glycan from a Group AB Blood Donor

\begin{tabular}{|c|c|c|c|c|c|}
\hline & \multicolumn{3}{|c|}{ Fetuin* } & \multicolumn{2}{|c|}{ CHIP } \\
\hline & \multicolumn{2}{|c|}{ Composition } & $\begin{array}{c}\text { Ratio* } \\
\text { expected }\end{array}$ & Composition & $\begin{array}{c}\text { Ratio }^{6} \\
\text { calculated }\end{array}$ \\
\hline & nmol & $\mathrm{mol} / \mathrm{mol}$ & & nmol & \\
\hline Fucose & 0 & 0 & 0 & 0.15 & 3.3 \\
\hline GalNAc & 0.49 & 4.0 & 3 & 0.17 & 3.6 \\
\hline GlcNAc & 2.27 & 18.6 & 15 & 0.67 & 14.4 \\
\hline Galactose & 1.65 & 13.5 & 12 & 0.42 & 9.0 \\
\hline Mannose & 1.17 & 9.6 & 9 & 0.14 & 3.0 \\
\hline
\end{tabular}

* Composition corresponds to monosaccharides recovered from 0.122 nmol of fetuin. The expected ratios of monosaccharides were obtained from published analyses (44). $\quad{ }^{\ddagger}$ Composition corresponds to monosaccharides recovered from $0.2 \mathrm{nmol}$ of CHIP. An efficiency of $\sim 25 \%$ resulted from the alcohol precipitation step before hydrolysis (see Methods). 'To estimate the monosaccharide composition of an individual CHIP-glycan, the quantity of each monosaccharide was normalized to the quantity of mannose which exists as a tri-mannose core in the polylactosaminoglycan on band 3 (25).

The accessibility of the glycan at the red cell surface was evaluated by incubating intact red cells with Peptide: $N$-glycosidase F. When assessed by anti-CHIP immunoblot, the electrophoretic mobility of glyCHIP was not altered by this digestion (Fig. 3). The same blots were stripped and incubated with antiglyRh, an antibody specific for the $50-\mathrm{kD}$ glycosylated subunits of the $\mathrm{Rh}$ antigens ( $\mathrm{Rh} 50 \mathrm{~A})$ (32), and complete digestion to the 30-kD core peptide was confirmed. Inspection of silver-stained SDS-PAGE slabs also revealed increased mobility of glycophorin A after digestion. The inaccessibility of CHIP to Peptide: $\mathrm{N}$ glycosidase $F$ persisted even when intact red cells were previously digested with chymotrypsin (data not shown), suggesting that the glycosylation site was not inaccessible simply because of steric obstruction by other surface components. This inaccessibility was only observed while CHIP was in the membrane. SDS-denatured, purified CHIP is highly sensitive to Peptide: $N$-glycosidase $F$ digestion $(10,11)$, and octylglucoside solubilized, purified CHIP was also digested by the enzyme at high concentrations (data not shown).

Colton blood group antigens on Aquaporin CHIP. Membranes prepared from red cells of known Colton phenotypes were immunoblotted with anti-CHIP. Membranes from $\mathrm{Co}(\mathrm{a}+\mathrm{b}-)$ and $\mathrm{Co}(\mathrm{a}-\mathrm{b}+)$ individuals exhibited equivalently strong reactions over CHIP28 and glyCHIP subunits, whereas membranes from a $\mathrm{Co}(\mathrm{a}-\mathrm{b}-)$ sample (donor G.S.) gave no reaction (Fig. $4 A)$. Intact $\mathrm{Co}(\mathrm{a}+\mathrm{b}-), \mathrm{Co}(\mathrm{a}-\mathrm{b}+)$, and pooled red cells were reacted with anti-Co ${ }^{\mathrm{a}}$, anti-Co $\mathrm{Co}^{\mathrm{b}}$, or anti-Co3, and immunoprecipitates were analyzed on immunoblots with antiCHIP (Fig. 4 B). Anti-Co precipitated CHIP from $\mathrm{Co}(\mathrm{a}+\mathrm{b}-$ ) red cells but not from $\mathrm{Co}(\mathrm{a}-\mathrm{b}+)$ red cells. Conversely, anti$\mathrm{Co}^{\mathrm{b}}$ precipitated CHIP from $\mathrm{Co}(\mathrm{a}-\mathrm{b}+)$ red cells but not from $\mathrm{Co}(\mathrm{a}+\mathrm{b}-)$ red cells. Anti-Co3 is an antibody from a patient with the Colton null phenotype and reacts with red cells of all Colton phenotypes (33); anti-Co3 precipitated CHIP from pooled red cells (Fig. $4 \mathrm{~B}$ ). To assess the possibility that the Colton antigens are simple peptide epitopes, immunoblotting

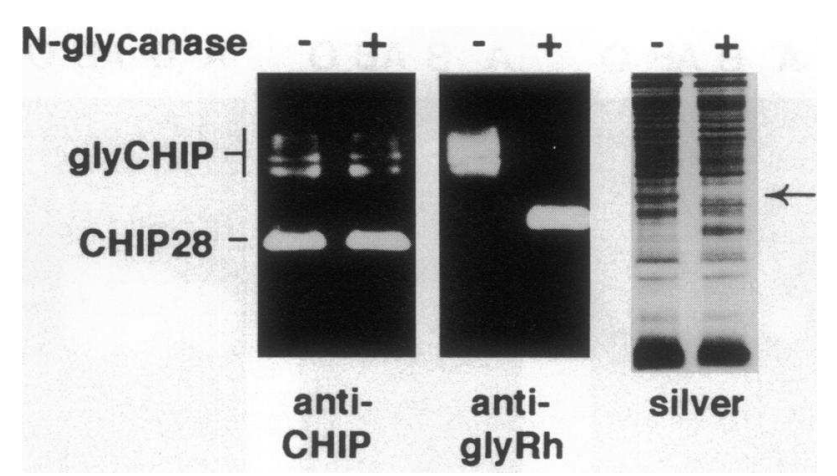

Figure 3. Digestion of intact red cells with Peptide: $N$-glycosidase $\mathrm{F}$. Washed red blood cells ( $25 \mu \mathrm{l}, 33 \%$ hematocrit) were incubated with $1 \mathrm{U}$ of glycerol-free Peptide: $N$-glycosidase F ( $\mathrm{N}$-glycanase) for $20 \mathrm{~h}$ at $37^{\circ} \mathrm{C}$ in $150 \mathrm{mM} \mathrm{NaCl}, 50 \mathrm{mM}$ sodium phosphate $(\mathrm{pH} \mathrm{7.4),} 1 \mathrm{mM}$ $\mathrm{Na}_{2}$ EDTA, $1 \mathrm{mg} / \mathrm{ml}$ D-glucose. Membranes immunoblotted with antiCHIP revealed no deglycosylation (left), whereas anti-glyRh demonstrated complete deglycosylation of the Rh glycopeptide (center) and silver staining of the SDS-PAGE slab revealed shift in the mobility of glycophorin A (right, arrow).

with anti-Co antisera was attempted on nitrocellulose filters containing purified CHIP, however, high background binding obscured interpretation. Attempts to immunoprecipitate SDSdenatured, nonglycosylated CHIP subunits were not successful, suggesting that linear peptide sequence alone may not comprise the $\mathrm{Co}^{\mathrm{a}}$ antigen. Extraction of red cell membranes with Triton $\mathrm{X}-100$ is known to solubize CHIP in its tetrameric form (11). Triton X-100-solubilized CHIP protein was immunoprecipitated with anti-Co ${ }^{\mathrm{a}}$ but not control plasma (Fig. $4 \mathrm{C}$ ), suggesting that the surface conformation of the protein may be required for antigenicity. Since the CHIP-associated glycan could not be removed by digestion of intact red cells with Peptide: $N$ glycosidase F (Fig. 3), hemagglutination studies using Colton antisera could not be used to determine the possible role of the oligosaccharide within Colton antigenic structures.

Molecular genetic analysis of Colton polymorphism. CHIP is encoded by Aquaporin-1, a gene which contains four exons (26). DNA was obtained from two unrelated individuals with each of the known Colton phenotypes: $\mathrm{Co}(\mathrm{a}+\mathrm{b}-), \mathrm{Co}(\mathrm{a}-\mathrm{b}+)$, and $\mathrm{Co}(\mathrm{a}+\mathrm{b}+)$. Each exon was amplified by polymerase chain reaction using primers corresponding to untranslated and intron sequences, and the nucleotide sequences of each coding region were determined by dideoxynucleotide sequencing. A single difference was noted at nucleotide 134 which was $C$ in DNA from the $\mathrm{Co}(\mathrm{a}+\mathrm{b}-)$ samples and $\mathrm{T}$ in the $\mathrm{Co}(\mathrm{a}-\mathrm{b}+)$ samples (Fig. $5 A$ ). This substitution will change the coding sequence at residue 45 from alanine in $\mathrm{Co}(\mathrm{a}+\mathrm{b}-)$ individuals to valine in $\mathrm{Co}(\mathrm{a}-\mathrm{b}+)$. DNA from $\mathrm{Co}(\mathrm{a}+\mathrm{b}+)$ individuals contained both nucleotides (not shown).

The first exon of CHIP contains a site for the restriction endonuclease PflMI which would cleave the 444 bp exon I PCR product into two fragments of $300 \mathrm{bp}$ and $144 \mathrm{bp}$ (18). The C to $T$ substitution at the codon for residue 45 was predicted to create a second PfIMI restriction site in CHIP exon I DNA from $\mathrm{Co}(\mathrm{a}-\mathrm{b}+)$ individuals. PflMI digestion would cut the $300 \mathrm{bp}$ fragment of $C o^{b}$ alleles into 174 and $126 \mathrm{bp}$ pieces (Fig. $5 \mathrm{~B}$ ). CHIP exon I DNA amplified from each of the Colton phenotypes was digested with PflMI and analyzed by polyacrylamide gel electrophoresis. Samples from two unrelated $\mathrm{Co}(\mathrm{a}+\mathrm{b}-)$ in- 


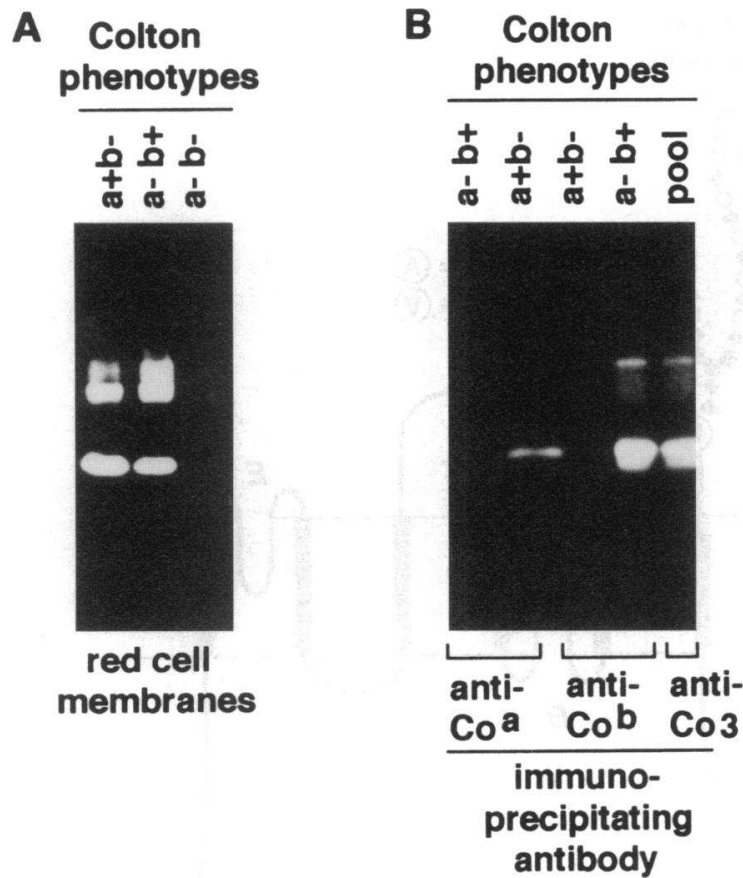

dividuals contained bands of $\sim 300$ and $144 \mathrm{bp}$, while samples from two unrelated $\mathrm{Co}(\mathrm{a}-\mathrm{b}+)$ individuals contained bands of $\sim 174,144$, and $126 \mathrm{bp}$. As expected, the samples from the unrelated $\mathrm{Co}(\mathrm{a}+\mathrm{b}+)$ individuals contained both patterns (Fig. 5 B).

\section{Discussion}

These studies have identified and characterized antigens from two different blood group systems on Aquaporin CHIP (Fig. 6 ). The oligosaccharide attached to asparagine- 42 resembles a band 3 polylactosaminoglycan with $\mathrm{ABH}$ determinants, and the Colton polymorphism was defined at residue 45 . These findings support the generally held view that blood group antigens are polymorphisms in red cell membrane surface structures. More importantly, evaluation of these CHIP-associated antigens has also provided new insight into the structure of the molecule and promises to provide further explanations for the importance of CHIP in transmembrane water movements.

Previous studies revealed that a subpopulation of 40-60kD CHIP subunits (glyCHIP) contained a large oligosaccharide which could be cleaved with Peptide: $N$-glycosidase $\mathrm{F}$ after the protein is denatured in SDS (10). Curiously, digestion of intact red cells with Peptide: $N$-glycosidase $\mathrm{F}$ failed to cleave the glycan (Fig. 3). Triton X-100-solubilized CHIP oligomers were quantitatively adsorbed onto wheat germ agglutinin-Sepharose, although free $28-\mathrm{kD}$ subunits were not, providing evidence that the protein is an oligomer (11). Additionally, the glycan was apparently attached to only a subpopulation of CHIP subunits in young and old red cells, indicating that deglycosylation was not ongoing (11). Substoichiometric glycosylation of CHIP was also found when the single CHIP cRNA was injected into Xenopus oocytes (14). Other integral membranes proteins are entirely glycosylated (e.g., band 3, glycophorins, and glucose transporters), although a few are entirely nonglycosylated and exist in the membrane in a complex with glycosylated polypeptides produced by different genes (e.g., the $30-\mathrm{kD} \mathrm{Rh}$ polypeptides) (32).
C

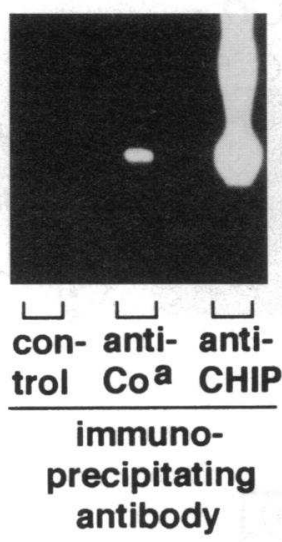

Figure 4. Anti-CHIP immunoblots of red cell membranes and Colton immunoprecipitates. (A) Membranes were prepared from red cells of defined Colton phenotypes and analyzed by immunoblot with anti-CHIP specific for the carboxy terminus or antibody specific for amino terminus (not shown). (B) Intact red cells of defined Colton phenotypes were reacted with the Colton-specific antisera (see Methods), and immunoprecipitates were analyzed by immunoblot. $(C)$ Membranes prepared from group $\mathrm{O}, \mathrm{Co}(\mathrm{a}+\mathrm{b}-)$ red cells were solubilized in Triton $\mathrm{X}-100$ and then reacted with group $O$ plasma (control), anti$\mathrm{Co}^{\mathrm{a}}$, or anti-CHIP, and immunoprecipitates were analyzed by immunoblot.
Substoichiometric glycosylation of CHIP may be explained by physical constraints at the surface glycosylation site which confer relative inaccessibility to glycosyltransferases during biogenesis or glycosidases during in vitro studies. Asparagine42 was identified as the only surface $N$-glycosylation site (19). If asparagine- 42 residues on individual subunits are located near each other while within the CHIP tetramer, the glycosyltransferases may gain access to only one potential site. Alternatively, glycosylation of asparagine- 42 may be hindered if it is located very close to the outer leaflet of the lipid bilayer. If CHIP subunits are oligomerized cotranslationally, three nonglycosylated CHIP28 subunits existing in a tetramer with one glyCHIP subunit will be rapidly targeted together to the Golgi apparatus and plasma membrane before unoccupied potential $N$-glycosylation sites are modified by the transferase. Consistent with this, studies of mutant CHIP molecules expressed in Xenopus oocytes revealed that dysfunctional mutants which were apparently retained in the endoplasmic reticulum were disproportionately glycosylated with high mannose glycans, all four subunits of certain CHIP mutants being glycosylated $(34,35)$. These studies endorse the hypothesis that substoichiometric glycosylation is a kinetic feature resulting from relative inaccessibility of asparagine- 42 .

Identification of the Colton polymorphism at residue 45 of CHIP resulted from the observation that the chromosomal loci both exist on the short arm of human chromosome $7(26,27)$. The presence of this protein blood group antigen at loop A of the CHIP polypeptide further supports the proposed membrane topology (19). It cannot be stated yet whether the glycan at asparagine- 42 contributes to the Colton recognition site at residue 45 , since it proved impossible to deglycosylate CHIP while the protein was imbedded in the membrane. Also, preliminary attempts to confer $\mathrm{Co}^{\mathrm{a}}$ antigenic sites on Xenopus oocytes expressing CHIP were unsuccessful, although other oocyte surface structures or altered glycosylations may obscure the antigen.

A potentially important benefit which may emerge from these studies may be the identification of humans with mutations 
A

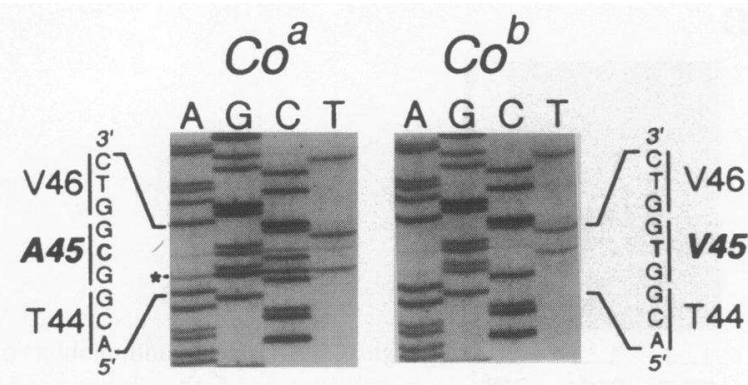

B
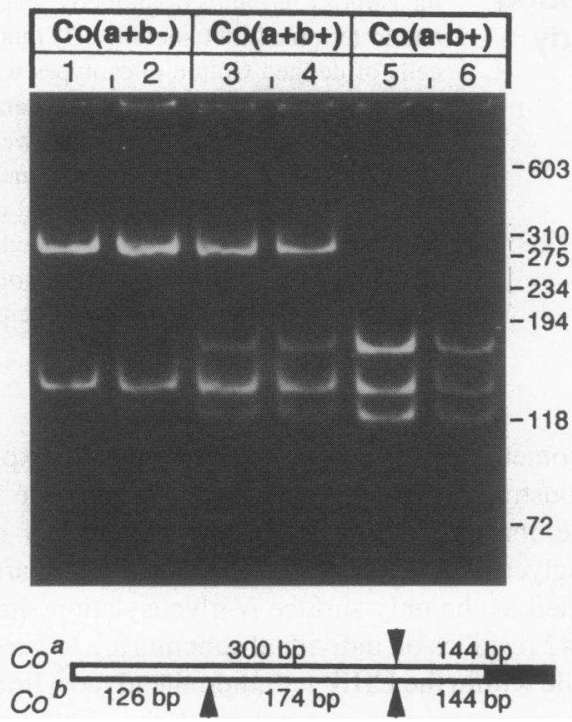

Figure 5. Molecular genetic identification of the Colton polymorphism. $(A)$ Dideoxynucleotide sequencing of exon I polymerase chain reaction product from DNA of a $\mathrm{Co}(\mathrm{a}+\mathrm{b}-)$ and a $\mathrm{Co}(\mathrm{a}-\mathrm{b}+)$ individual. A single nucleotide difference was identified $(\mathrm{C}$ and $\mathrm{T})$ resulting in a coding polymorphism (alanine and valine). Electrophoretic compression artifact is noted with an asterisk. (B) PflMI digestion patterns of the 444 bp exon I polymerase chain reaction product from DNA of individuals with defined Colton phenotypes. The diagram depicts the fragments of 300 and $144 \mathrm{bp}$ in $C o^{a}$ alleles and fragments of 126,174 , and $144 \mathrm{bp}$ in $\mathrm{Co}^{b}$ alleles.

in the coding sequence of CHIP or mutations affecting CHIP expression. Two common antithetical Colton antigens are known, $\mathrm{Co}^{\mathrm{a}}$ and $\mathrm{Co}^{\mathrm{b}}$. Approximately $92 \%$ of Caucasians are $\mathrm{Co}(\mathrm{a}+\mathrm{b}-)$, approximately $8 \%$ are $\mathrm{Co}(\mathrm{a}+\mathrm{b}+)$, and only $0.2 \%$ are $\mathrm{Co}(\mathrm{a}-\mathrm{b}+)(36)$. Colton antigens cause clinical difficulties very infrequently, although maternal-fetal incompatibility and transfusion reactions are known. The alanine-valine Colton polymorphism itself is unlikely to be of any functional significance, since residue 45 is leucine in murine CHIP cDNAs (37, 38 ). The power of world-wide blood group referencing makes the rarest of phenotypes accessible, and the single $\mathrm{Co}(\mathrm{a}-\mathrm{b}-)$ red cell membrane sample in the reference collection was found to lack CHIP by immunoblot. Only a few individuals have ever been reported to lack the Colton antigens. An association of Colton deficiency and monosomy 7 has been reported in some cases of leukemia $(39,40)$ and a Colton-deficient individual

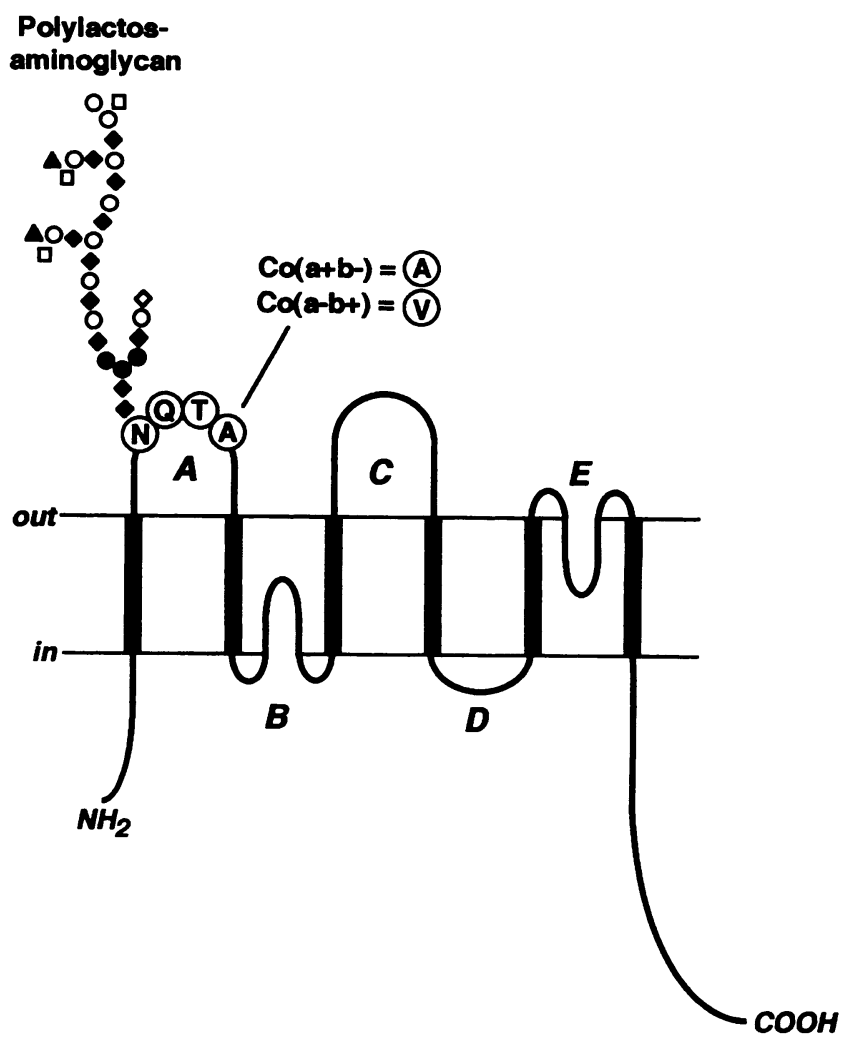

Figure 6. Membrane topology and structure of Aquaporin CHIP showing $\mathrm{ABH}$ and Colton antigens. The site of attachment at asparagine- 42 and potential structure of the polylactosaminoglycan (adapted from reference 45) are illustrated. $N$-acetylglucosamine, $\bullet$; mannose, $\bullet$; galactose, $\bigcirc ; N$-acetylgalactosamine, $\Delta$; fucose, $\square$; or sialic acid, $\diamond$. The site of the Colton polymorphism at residue 45 is represented: $\mathrm{Co}^{\mathrm{a}}$, alanine $(A)$; and $\mathrm{Co}^{\mathrm{b}}$, valine $(V)$.

with congenital dyserythropoietic anemia has been identified $(41,42)$. Three other $\mathrm{Co}(\mathrm{a}-\mathrm{b}-)$ individuals were recently found with mutations in Aquaporin-1 and lacked CHIP water channels (43). Future studies of these $\mathrm{Co}(a-b-)$ individuals are planned to further probe the roles of Aquaporin CHIP.

\section{Acknowledgments}

We thank Kenneth Greis, Gerald Hart, R. Sue Shirey, Colvin Redman, and Marion Reid for helpful discussions. We also thank Graham Rowe and Tony Napier for providing $\mathrm{Co}(\mathrm{a}-\mathrm{b}+)$ samples and Gary Mallinson for preparing genomic DNA from donors of known Co phenotype.

Support for this study was provided by National Institutes of Health grants HL-33991 and HL-48269.

\section{References}

1. Daniels, G. L., J. J. Moulds, D. J. Anstee, G. W. G. Bird, E. Brodheim J.-P. Cartron, W. Dahr, C. P. Engelfriet, P. D. Issitt, J. Jorgenson, et al. 1993. ISBT working party on terminology for red cell surface antigens, São Paulo report. Vox Sang. 65:77-80.

2. Yamamoto, F., H. Clausen, T. White, J. Marken, and S. Hakomori. 1990. Molecular genetic basis of the histo-blood group ABO system. Nature (Lond.). 345:229-233.

3. Anstee, D. J. 1981. The blood group MNSs active-sialoglycoproteins. Semin. Hematol. 18:13-31.

4. Cartron, J.-P., and J. London. 1992. The protein and gene structure of red cell glycophorins. In Protein Blood Group Antigens of the Human Red Cell. P. 
Agre and J. P. Cartron, editors. Johns Hopkins University Press, Baltimore. 101 151.

5. Telen, M. J., and J. A. Chasis. 1990. Relationship of the human erythrocyte $\mathrm{Wr}^{\mathrm{b}}$ antigen to an interaction between glycophorin $\mathrm{A}$ and band 3. Blood. 76:842848 .

6. Cherif-Zahar, B., C. Bloy, C. Le van Kim, D. Blanchard, P. Bailly, P. Hermand, C. Salmon, J. P. Cartron, and Y. Colin. 1990. Molecular cloning and protein structure of a human blood group Rh polypeptide. Proc. Natl. Acad. Sci. USA. 87:6243-6247.

7. Avent, N. D., K. Ridgwell, M. J. Tanner, and D. J. Anstee. 1990. cDNA cloning of a $30 \mathrm{kDa}$ erythrocyte membrane protein associated with Rh (Rhesus)blood-group-antigen expression. Biochem. J. 271:821-825.

8. Lee, S., E. Zambas, W. L. Marsh, and C. M. Redman. 1991. Molecular cloning and primary structure of Kell blood group protein. Proc. Natl. Acad. Sci. USA. 88:6353-6357.

9. Chaudhuri, A., J. Polyakova, V. Zbrzezna, K. Williams, S. Gulati, and A. O. Pogo. 1993. Cloning of the glycoprotein-D cDNA, which encodes the major subunit of the Duffy blood group system and the receptor for the plasmodium vivax malaria parasite. Proc. Natl. Acad. Sci. USA. 90:10793-10797.

10. Denker, B. M., B. L. Smith, F. P. Kuhajda, and P. Agre. 1988. Identification, purification, and characterization of a novel $M_{\mathrm{r}} 28,000$ integral membrane protein from erythrocytes and renal tubules. J. Biol. Chem. 263:15634-15642.

11. Smith, B. L., and P. Agre. 1991. Erythrocyte $M_{\mathrm{r}} 28,000$ transmembrane protein exists as a multi-subunit oligomer similar to channel proteins. J. Biol. Chem. 266:6407-6415.

12. Sabolic, I., G. Valenti, J. M. Verbavatz, A. N. Van Hoek, A. S. Verkman, D. A. Ausiello, and D. Brown. 1992. Localization of the CHIP28 water channel in rat kidney. Am. J. Physiol. 263:1225-1233.

13. Nielsen, S., B. L. Smith, E. I. Christensen, M. A. Knepper, and P. Agre. 1993. CHIP28 water channels are localized in constitutively water-permeable segments of the nephron. J. Cell Biol. 120:371-383.

14. Preston, G. M., T. P. Carroll, W. B. Guggino, and P. Agre. 1992. Appearance of water channels in Xenopus oocytes expressing red cell CHIP28 protein. Science (Wash. DC). 256:385-387.

15. Zeidel, M. L., S. V. Ambudkar, B. L. Smith, and P. Agre. 1992. Reconstitution of functional water channels in liposomes containing purified red cell CHIP28 protein. Biochemistry. 31:7436-7440.

16. Agre, P., S. Sasaki, and M. J. Chrispeels. 1993. Aquaporins: a family of water channel proteins. Am. J. Physiol. 265:F461.

17. Agre, P., G. M. Preston, B. L. Smith, J. S. Jung, S. Raina, C. Moon, W. B. Guggino, and S. Nielsen. 1993. Aquaporin CHIP, the archetypal molecular water channel. Am. J. Physiol. 265:F463-F476.

18. Preston, G. M., and P. Agre. 1991. Molecular cloning of the red cell integral membrane protein of $M_{\mathrm{r}} 28,000$ : a member of an ancient channel family. Proc. Natl. Acad. Sci. USA. 88:11110-11114.

19. Preston, G. M., J. S. Jung, W. B. Guggino, and P. Agre. 1994. Membrane topology of Aquaporin CHIP: analysis of functional epitope-scanning mutants by vectorial proteolysis. J. Biol. Chem. 269:1668-1673.

20. Verbavatz, J.-M., D. Brown, I. Sabolić, G. Valenti, D. A. Ausiello, A. N. Van Hoek, T. Ma, and A. S. Verkman. 1993. Tetrameric assembly of CHIP28 water channels in liposomes and cell membranes: a freeze-fracture study. J. Cell. Biol. 123:605-618.

21. Zeidel, M. L., S. Nielsen, B. L. Smith, S. V. Ambudkar, A. B. Maunsbach, and P. Agre. 1994. Ultrastructure, pharmacologic inhibition, and transport selectivity of Aquaporin channel-forming integral protein in proteoliposomes. Biochemistry. 33:1606-1615.

22. Walz, T., B. L. Smith, M. L. Zeidel, A. Engel, and P. Agre. 1994. Biologically active two-dimensional crystals of Aquaporin CHIP. J. Biol. Chem. 269:1583-1586.

23. Agre, P., A. M. Saboori, A. Asimos, and B. L. Smith. 1987. Purification and partial characterization of the $M_{\mathrm{r}} 30,000$ integral membrane protein associated with the erythrocyte Rh(D) antigen. J. Biol. Chem. 262:17497-17503.

24. Saboori, A. M., B. L. Smith, and P. Agre. 1988. Polymorphism in the $M_{\mathrm{r}}$ 32,000 $\mathrm{Rh}$ protein purified from $\mathrm{Rh}(\mathrm{D})$-positive and -negative erythrocytes. Proc. Natl. Acad. Sci. USA. 85:4042-4045.
25. Fukuda, M., A. Dell, and M. N. Fukuda. 1984. Structure of fetal lactosaminoglycan. J. Biol. Chem. 259:4782-4791.

26. Moon, C., G. M. Preston, C. Griffin, E. W. Jabs, and P. Agre. 1993. The human Aquaporin CHIP gene: structure, organization, and chromosomal localization. J. Biol. Chem. 268:15772-15778.

27. Zelinski, T., H. Kaita, T. Gilson, G. Coghlan, S. Philipps, and M. Lewis. 1990. Linkage between the Colton blood group locus and ASSP11 on chromosome 7. Genomics. 6:623-625.

28. Laemmli, U. K. 1970. Cleavage of structural proteins during assembly of the head of bacteriophage $T_{4}$. Nature (Lond.). 227:680-685.

29. Mallinson, G., P. G. Martin, D. J. Anstee, M. J. A. Tanner, A. H. Merry, D. Tills, and H. H. Sonneborn. 1986. Identification and partial characterisation of the human erythrocyte membrane component(s) that express the antigens of the LW blood group system. Biochem. J. 234:649-652.

30. Bennett, V. 1983. Proteins involved in membrane-cytoskeleton association in human erythrocytes: spectrin, ankyrin, band 3. Methods Enzymol. 96:313-324.

31. Sambrook, J., E. G. Fritsch, and T. Maniatis. 1989. Molecular Cloning: A Laboratory Manual. 2nd Edition. Cold Spring Harbor Laboratory, Cold Spring, Harbor, NY. 6.2-6.62.

32. Ridgwell, K., S. A. C. Eyers, W. J. Mawby, D. J. Anstee, and M. J. A. Tanner. 1994. Studies on the glycoprotein associated with Rh (Rhesus) blood group antigen expression in the human red blood cell membrane. J. Biol. Chem. 269:6410-6416.

33. Lacey, P. A., J. Robinson, M. L. Collins, D. G. Bailey, C. C. Evans, J. J. Moulds, and G. L. Daniels. 1987. Studies on the blood of a $\mathrm{Co}(\mathrm{a}-\mathrm{b}-)$ proposita and her family. Transfusion (Bethesda). 27:268-271.

34. Preston, G. M., J. S. Jung, W. B. Guggino, and P. Agre. 1993. The mercury-sensitive residue at cys-189 in the CHIP28 water channel. J. Biol. Chem. 268:17-20.

35. Jung, J. S., G. M. Preston, B. L. Smith, W. B. Guggino, and P. Agre 1994. Molecular structure of the water channel through Aquaporin CHIP: the tetrameric-hourglass model. J. Biol. Chem. 269:14648-14654.

36. Mollison, P. L., C. P. Engelfriet, and M. Contreras. 1987. Other red cell antigens. In Blood Transfusion in Clinical Medicine. 8th Edition. Blackwell Scientific Publications Ltd., Oxford. 399.

37. Lanahan, A., J. B. Williams, L. K. Sanders, and D. Nathans. 1992. Growth factor-induced delayed early response genes. Mol. Cell. Biol. 12:3919-3929.

38. Deen, P. M. T., J. A. Dempster, B. Wieringa, and C. H. Van Os. 1992 Isolation of a cDNA for rat CHIP28 water channel: high mRNA expression in kidney cortex and inner medulla. Biochem. Biophys. Res. Commun. 188:12671273.

39. de la Chapelle, A., P. Vuopio, R. Sanger, and P. Teesdale. 1975. Monosomy 7 and the Colton blood groups. Lancet. ii:817.

40. Pasquali, F., P. Bernasconi, R. Casalone, M. Fraccaro, C. Bernasconi, M. Lazzarino, E. Morra, E. P. Alessandrino, M. A. Marchi, and R. Sanger. 1982. Pathogenic significance of "pure" monosomy 7 in myeloproliferative disorders. Analysis of 14 cases. Hum. Genet. 62:40-51.

41. Parsons, S. F., J. Jones, D. J. Anstee, P. A. Judson, B. Gardner, E. Wiener, J. Poole, N. Illum, and S. N. Wickramasinghe. 1994. A novel form of congenital dyserythropoietic anemia associated with deficiency of erythroid CD44 and a unique blood group phenotype $[\ln (\mathrm{a}-\mathrm{b}-), \mathrm{Co}(\mathrm{a}-\mathrm{b}-)]$. Blood. 83:860-868.

42. Agre, P., B. L. Smith, R. Baumgarten, G. M. Preston, E. Pressman, P. Wilson, N. Illum, D. J. Anstee, M. B. Lande, and M. L. Zeidel. 1994. Human red cell Aquaporin CHIP. II. Expression during normal fetal development and in a novel form of congenital dyserythropoietic anemia. J. Clin. Invest. 94:10501058 .

43. Preston, G. M., B. L. Smith, M. L. Zeidel, J. J. Moulds, and P Agre. 1994 Aquaporin-1 mutations in phenotypically normal humans without functional CHIP water channels. Science (Wash. DC). In press.

44. Hardy, M. R., R. R. Townsend, and Y. C. Lee. 1988. Monosaccharide analysis of glyconjugates by anion exchange chromatography with pulsed amperometric detection. Anal. Biochem. 170:54-62.

45. Fukuda, M. N., K. A. Masri, A. Dell, E. J.-M. Thonar, G. Klier, and R. M. Lowenthal. 1989. Defective glycosylation of erythrocyte membrane glycoconjugates in a variant of congenital dyserythropoietic anemia type II. Blood. 73:1331-1339. 